\author{
В. В. Тротнер (Приймачук) \\ Криворізький професійний гірничо-металургійний ліщей
}

\title{
ЗНАХІДКИ РІДКІСНИХ ВИДІВ РОСЛИН НА КРИВОРІЖЖІ
}

Наведено дані про авторські знахідки рідкісних видів флори, які занесено до Червоної книги України та до Червоної книги Дніпропетровської області. Усього знайдено 12 видів, з них 1 - вперше для України та 1 - вперше для Дніпропетровщини і Криворіжжя. Для 10 видів наведено нові локалітети

Ключові слова: рідкісні види, флора, Криворіжжя, Червона книга, локалітет.

\section{В. В. Тротнер (Приймачук)}

Криворожский профессиональньй горно-металлургический лицей

\section{НАХОДКИ РЕДКИХ ВИДОВ РАСТЕНИЙ КРИВОРОЖЬЯ}

Приведены данные об авторских находках редких видов флоры, занесенных в Красную книгу Украины и в Красную книгу Днепропетровской области. Всего найдено 12 видов, из них 1 - впервые для Украины и 1 - впервые для Днепропетровщины и Криворожья. Для 10 видов приведены новые локалитеты.

Ключевые слова: редкие виды, флора, Красная книга.

$$
\begin{aligned}
& \text { V. V. Trotner (Pryimachuk) } \\
& \text { Kryvyi Rih Mining and Metallurgical Professional Lyceum }
\end{aligned}
$$

\section{FINDS OF RARE PLANTS IN THE KRYVYI RIH REGION}

Data about the author finds of rare species of flora listed in the Red Book of Ukraine and the Red Book of Dnepropetrovsk region. Total found 12 species.

For the first time found a new natural flora Ukraine alien species Miscanthus sacchariflorus (Maxim.) Benth., and only in the Dnipropetrovsk region locality Gymnospermium odessanum (DC) Takht., which before were considered missing.

Identified new locations of 10 types of rare and endangered plants: Rosa villosa L., Marchantia polymorpha L., Galega officinalis L., Sanguisorba officinalis L., Allium podolicum (Asch. et Graebn.) Blocki ex Racib., Ornithogalum kochii Meeting., Cotoneaster melanocarpus Fisch. ex Blytt, Ephedra distachya L., Glycyrrhiza glabra L., Bulbocodium versicolor (Ker Gawl.) Spreng. Of these, 4 species Glycyrrhiza glabra L., Gymnospermium odessanum (DC.) Takht, Bulbocodium versicolor (Ker Gawl.) Spreng listed in the Red book of Ukraine, 6 species in the Red book of the Dnipropetrovsk region.

Keywords: rare species, flora, Kryvorizhzhya, the Red Book, localities.

Рослинний покрив Криворіжжя зазнає постійного техногенного і антропогенного навантаження. У природних фітоценозах знижується видове різноманіття. Тому важливим питанням $є$ інвентаризація сучасного стану флори та визначення наявності в іiі складі рідкісних видів, які є чутливими індикаторами зміни навколишнього середовища й важливими показниками стану збереженості природних комплексів певної території.

Дослідженням флори Криворіжжя в останні роки займалися такі автори: Кучеревський В. В. [6; 7; 8], Шоль Г. Н. [5; 6; 17; 18], Красова О. О. [4] та ін. Зокрема, досить докладно вивчено урбанофлору м. Кривого Рогу [6; 17; 18]. На сьогодні в ній нараховується 1084 види рослин, з яких 157 занесено до Червоних книг України та Дніпропетровщини і різних охоронних списків $[5 ; 15 ; 16]$.

Кожна нова достовірна інформація про локалітети рідкісних видів має особливу цінність для збереження біорізноманіття. Тому виявлені нами нові місце-

(C) В. В. Тротнер (Приймачук), 2016 
знаходження таких видів не тільки доповнюють відомості про поширення созофітів на Криворіжжі зокрема й на Дніпропетровщині загалом, але й додатково підкреслюють високе созологічне значення цієї території.

Матеріали та методи дослідження. Об'єктом нашого дослідження протягом 2004-2016 рр. стали рідкісні види рослини, які зростають у межах Криворізького регіону. Дослідження здійснювали маршрутним методом зі збором гербарного матеріалу та камеральною обробкою зразків. Географічні координати нових місцезнаходжень видів визначали за допомогою GPS-навігатора. Назви рослин наведено згідно із загальноприйнятим в Україні зведенням [20].

Результати досліджень та їх обговорення. Район досліджень охоплює територію центрального і західного Криворіжжя, яка за геоботанічним районуванням розміщена в межах Дністровсько-Дніпровського геоботанічного округу Середньо-придніпровського флористичного району [2].

Тут нами було вперше знайдено новий для природної флори України адвентивний вид Miscanthus sacchariflorus (Maxim.) Benth., а також єдиний на Дніпропетровщині локалітет Gymnospermium odessanum (DC) Takht., який до того вважався зниклим. Ми виявили нові місцезнаходження 10 видів рідкісних і зникаючих рослин: Rosa villosa L., Marchantia polymorpha L., Galega officinalis L., Sanguisorba officinalis L., Allium podolicum (Asch. et Graebn.) Blocki ex Racib., Ornithogalum kochii Parl., Cotoneaster melanocarpus Fisch. ex Blytt, Ephedra distachya L., Glycyrrhiza glabra L., Bulbocodium versicolor (Ker Gawl.) Spreng. 3 них 4 види Glycyrrhiza glabra L., Gymnospermium odessanum (DC.) Takht, Bulbocodium versicolor (Ker Gawl.) Spreng занесено до Червоної книги України і 6 видів - до Червоної книги Дніпропетровської області.

Наводимо перелік встановлених нами видів з відповідною інформацією про їх созологічну цінність, місцезростання, площу популяцій, наявність видів у наукових гербаріях та колекціях:

1. Новий для природної флори України вид - міскантус цукроквітковий Miscanthus sacchariflonis (Maxim.) Benth.

У районі Карачунівських гранітних відслонень, на березі р. Інгульця 07.07.16 р. ми знайшли невелику популяцію рослини міскантусу цукроквіткового Miscanthus sacchariflorus (Maxim.) Benth.(рис.1), який не $\epsilon$ аборигенним видом нашої флори, а культивованою рослиною, що з'явилася в природному фітоценозі. Ми вважаємо, що цей вид був занесений сюди насінням, ймовірно з ближніх дачних ділянок.

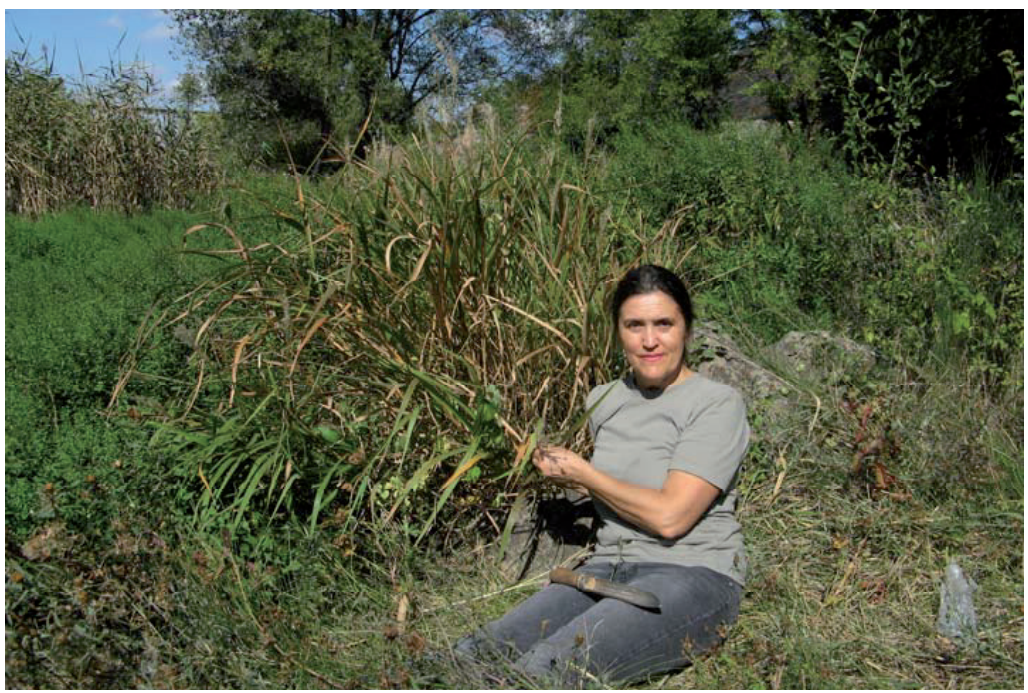

Рис. 1. Міскантус цукроквітковий на березі р. Інгулець, 17.09.2016 р. 
У своєму природному ареалі міскантус цукроквітковий зростає по вологих долинах річок, лісових галявинах, відкритих кам'янистих схилах від Амурської області до півдня Приморського краю Росії, в Японії, Маньчжурії, Кореї. Там він розмножується як насінням, так і вегетативно. Головний експерт з міскантусів, д.с.-г.н., професор Д. Б. Рахметов з Ботанічного саду ім. Гришка повідомив нам, що у природній флорі України він цю рослину не спостерігав: «Це вегетативно рухливий вид. В умовах України мені не відомо насіннєве розмноження. 3 нашого генофонду тільки окремі форми м. китайського і м. цукроквіткового можуть формувати насіння».

У культурі міскантуси розмножуються вегетативно (ризомами), але для цього місцезростання таке походження є повністю виключеним, тому що коренева система рослини розташована під гранітною брилою, куди її посадити ризомами неможливо. Ми не виявили в літературних джерелах і усних повідомленнях криворізьких і дніпропетровських флористів інформації про знахідки цього виду в природних фітоценозах нашого регіону. Але на Криворіжжі ця рослина може вирощуватися на присадибних ділянках як екзотичний злак. Так, у с. Надеждівка (північно-східне Криворіжжя) міскантус культивується у приватному розпліднику і продається двічі на рік на садових ярмарках за ціною 80 грн. за 1 шт. Також він дає насіння, але сіянці мають гірші декоративні ознаки, ніж рослини, розмножені вегетативно.

У 2015 р. ми знайшли Miscanthus $\boldsymbol{x}$ giganteus в культурі, в Центрально-Міському районі Кривого Рогу (зупинка транспорту - вул. Балхашська). Великий кущ цієї рослини росте у приватній садибі по вул. Івана Франка, 5. У Криворізькому ботанічному саду, в колекції природної флори є екземпляр міскантусу китайського Miscanthus sinensis Andersson, привезеного Кучеревським В. В. із Ботанічного саду Житомирського національного агроекологічного університету. Ця рослина суцвіть і насіння не дає, а знайдений нами міскантус цукроквітковий цвіте й плодоносить.

Міскантус належить до відділу покритонасінних (Angispermal), класу однодольні (Monocatyledoneae), родини злакові (Gramineae), підродини просові (Рanicoideae). Відомо близько 40 видів, які поширені у тропічній, субтропічній Азії, Африці, Австралії, а також у помірно-теплих зонах Сходу Росії. Це багаторічні трави, висотою 1-6 м. Назва роду в перекладі з грецької означає «mischos»ніжка, «anthos» - квітка та пов'язана зі способом кріплення колосків. Рослини утворюють великі, пухкі дернини 3 повзучими підземними пагонами. Стебла прямі. Листкові пластинки лінійні. Коренева система потужна, глибока та сягає до 2,5 метрів вглиб грунту. Це дозволяє вирощувати його на середньо-щільних грунтах 3 низьким рівнем грунтових вод. Рослини активно культивуються в Свропі та Північній Америці. Види роду міскантус характеризуються високим урожаєм, морозостійкістю та швидким ростом. Використовуються в якості біопалива [11].

У тропічних та субтропічних районах Північної Америки натуралізовані M. sinensis та M. sacchariflorus вважаються бур'янами та належать до інвазійних видів. Широко проводяться дослідження їх біохімічних та фізіологічних особливостей, на основі яких обидва види пропонуються як джерело для отримання целюлози та біоетанолу в зонах, де вони не формують насіння. У відділі квітководекоративних рослин Національного ботанічного саду НАН України створено колекцію з видів Miscanthus, інтродукованих ще у 80-х роках, а також видів та copтів, інтродукція яких відбувається з 2006 року. Сьогодні вона нараховує 2 види роду Miscanthus (M. sinensis і M. sacchariflorus) та 6 сортів: 'Graziella', 'Kleine Fontane', 'Kleine Silberspinne', 'Strictus', 'Variegatus', 'Zebrinus' [19]. Провідними установами з селекції міскантусу в Україні $є$ Інститут біоенергетичних культур та цукрових буряків НААН, Національний ботанічний сад ім. М.М. Гришка НАAН 
та ТОВ «АМАКО Україна». Перші плантації в Україні було закладено в 20062007 роках у Житомирській і Вінницькій областях.

12.09.16 р. гербарний зразок знайденого нами Miscanthus sacchariflorus (Maxim.) Benth було передано до гербаріїв $D S U$ i $K R W *$ * Зважаючи на унікальність цієї знахідки для адвентивної флори України, ми плануємо подальші дослідження цього локалітету та біології міскантусу в природних умовах. Це дуже агресивна рослина, яка за сприятливих умов може стати домінантним видом у цьому районі і витіснити рідкісні созофіти з даної території.

2. Сдине місцезнаходження Gymnospermium odessanum (DC) Takht. на Дніпропетровщині.

У березні 2005 року ми знайшли рослину, яка вважалася зниклою в Дніпропетровській області - голонасінник одеський Gymnospermium odessanum (DC) Takht., занесений до Червоної книги України та Світового Червоного списку. Місце її зростання - історико-геологічна пам'ятки природи місцевого значення «Сланцеві скелі» в Саксаганському районі м. Кривого Рогу. Цій знахідці посприяла керівник гуртка Жовтневої станції юннатів м. Кривого Рогу Квітка О. В. Вид вказувався в нашому регіоні як зниклий $[9 ; 10 ; 15 ; 16 ; 18]$. Тепер ця знахідка зазначена у Червоній книзі Дніпропетровської області (Рослинний світ) (2010). Гербарні зразки передано до гербарію Інституту ботаніки ім. Холодного $(K W)$ та DSU у 2006 році.

Живі зразки рослин надано для вирощування у приватних колекціях й успішно культивуються вже багато років садівниками-аматорами Криворіжжя (Рибачук О. В., Стециною В. Ф., Білоусовим В. В.). Зазначено, що в культурних насадженнях насіння голонасінника розноситься мурахами, а це сприяє його поширенню на значній території. Також цей вид культивується у Криворізькому ботанічному саду НАНУ (зразки є в гербарії Саду).

Особлива цінність цієї знахідки полягає в тому, що локалітети голонасінника розташовані в зоні техногенного забруднення, а саме - поруч $з$ шахтами «Артем-1» та «Північна» й Кіровським кар'єром.

За нашими даними, на цій території в межах правого берега старого русла $\mathrm{p}$. Саксагань, від шахти «Артем-1» до вул. Кільцевої, зростають близько 20 видів рідкісних видів. Тому, зважаючи на велику наукову, фітосозологічну, ландшафтно-естетичну та еколого-виховну цінність цієї території, ми склали наукове обгрунтування і запропонували взяти територію під охорону на правах ботанічного заказника місцевого значення.

\section{3. Нове місцезнаходження Rosa pomifera Herrm. на Дніпропетровщині.}

У 2004 році ми знайшли шипшину яблучну Rosa pomifera Herrm. (Rosa villo$\boldsymbol{s} \boldsymbol{a} \mathbf{L}$.$) , в межах Центрально-Міського р-ну Кривого Рогу. Згідно із сучасними ви-$ значниками, цей вид зустрічається - в Розточчі-Опіллі, Поліссі, Лісостепу, в північних районах Степу, в Криму [12]. Знайдений нами локалітет розташований в середньо-степовій підзоні Степу, для якої він не характерний. У Червоній книзі Дніпропетровської області цей вид відсутній.

В. В. Тарасов (2012) зазначає його для Дніпропетровщини лише в таких 4 місцях: балка Гракова (Б. О. Барановський, 2008), м. Дніпропетровськ, на узбіччі дороги на вул. Героїв Сталінграда (В. В. Тарасов, 2012!), по р. Саксагань (В. М. Сидоров, 1897). Зокрема, Сидоров В. М. у 1897 р. подавав такі дані: «136) R о s a415. - villosa L. Ясинов., Сакс. (Слеп.). Май.». Судячи з назви, це село Ясинувате Запорізької області, на лівому березі Дніпровського водосховища, на межі $з$ Дніпропетровською областю. Позначення Сакс. - станція Саксагань Катерининської залізниці (північне Криворіжжя), або річка Саксагань. Але де саме по ній зустрічалася рослина, не відомо.

Місце знаходження сучасної популяції, яку знайшли ми - західна околиця Кривого Рогу і тут єдина річка - Інгулець. Вид зростає на околиці селища Все- 
братське, в балці поміж дачами, відвалами кар'єру НКГЗК і новим Всебратським кладовищем. Площа балки близько 0,75 га. Це територія колишнього вапнякового кар'єру, який існував тут у 1950 -х роках. Географічні координати: широта $47^{0}$ 52' 163", довгота $33^{0} 16^{\prime} 241^{\prime \prime}$, висота над рівнем моря 69,5 м. Локалітет складається 32 частин, які тягнуться здовж стежки по днищу балки. Права частина має розміри 2 х 6 м, ліва - 6 × 9 м. Висота генеративних пагонів до 1 м. На території балки наявна 1 велика і 3 невеликих синузії Rosa pomifera Herrm. Зустрічаються такі рідкісні рослини: ковила Лессінга, астрагал пухнастоквітковий, ломиніс цілолистий, брандушка різнокольорова, раніше зустрічався тюльпан бузький. Ще одна синузія шипшини волохатої розташована неподалік балки, на західній межі Всебратського кладовища. Тут присутня невелика кількість кущів терену та Bryonia alba $\mathrm{L}$.

Грунтові умови тут досить складні: родючий шар слабогумусного чорнозему товщиною близько 1,5 см (!), під ним - вапняк, на якому і ростуть кореневища шипшини волохатої. Балка знаходиться під величезним антропогенним пресом сюди регулярно вивозиться побутове і будівельне сміття, тут випасають домашню худобу і випалюють степ, тому цей локалітет постійно знаходиться під загрозою знищення. Необхідні заходи охорони цієї території.

Насіннєвий матеріал передано до відділу природної флори КБС восени 2011 р., але в колекції та гербарії Саду цей вид відсутній. Наразі ця знахідка на Криворіжжі - перша і єдина. В 2012 р. гербарні зразки передано в DSU.

4. Сдине і нове для Криворіжжя для Дніпропетровщини місцезнаходження Marchantia polymorpha L.

Маршанція поліморфна Marchantia polymorpha L. - рідкісний для Дніпропетровщини вид мохів з відділу Печінкові мохи (Marchantiophyta) родини Маршанцієвих. Піонерний вид на незаселених субстратах. Зростає на скелях, стінах, вологих місцях з поганим освітленням, болотах, по берегах водойм, у лісах, на згарищах. Згідно з літературними даними, в нашій області відомо лише кілька місць іiі зростання [18].
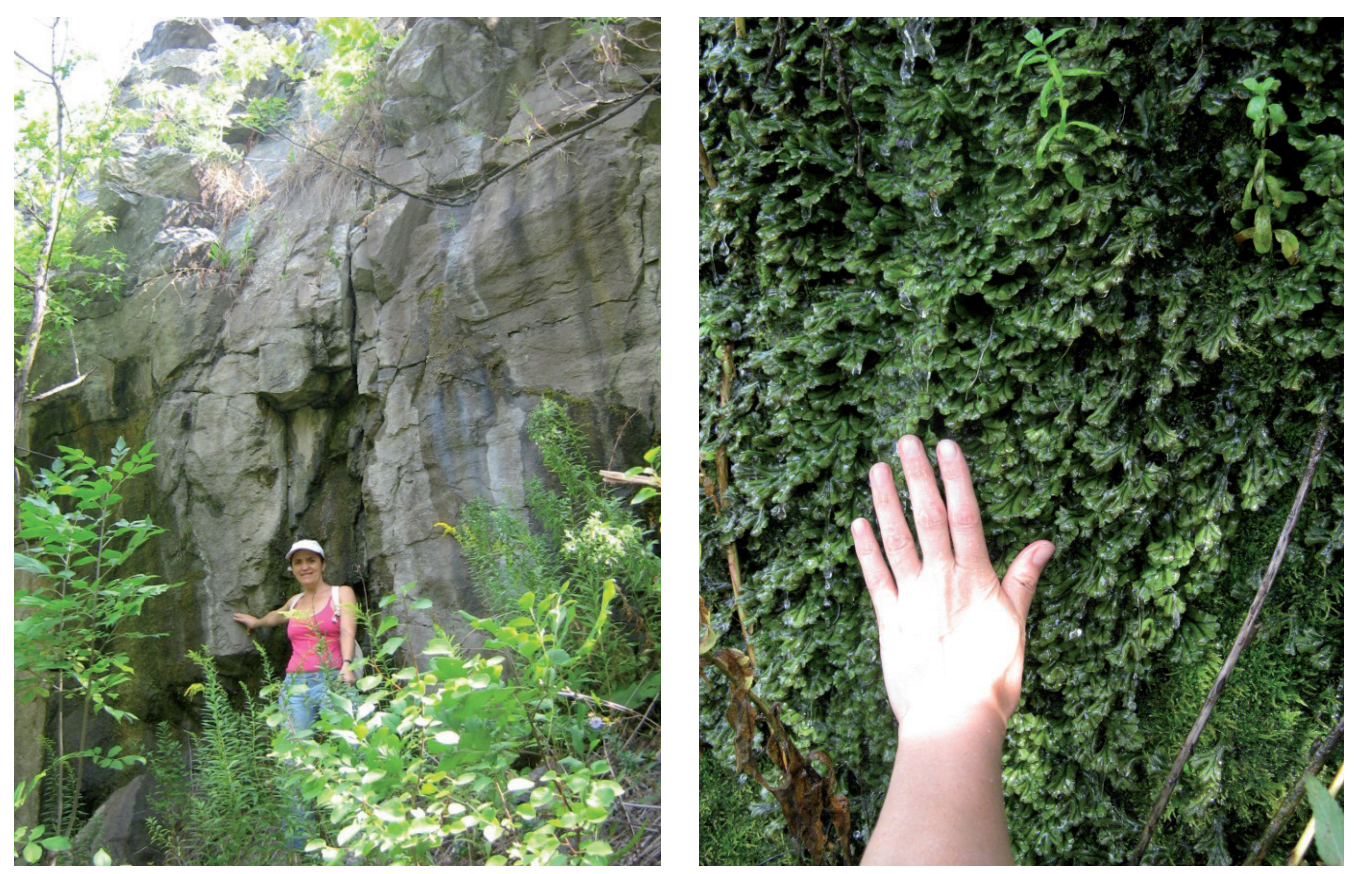

Рис. 2. Маршанція в Карачунівському гранітному кар'єрі, 2007 р. і 2016 р. 
Для Кривого Рогу ця рослина зазначалася Гаєвою Н. В. у 1964 р. в районі колишнього Ботанічного саду педінституту (сучасна пл. Визволення), але цей екотоп вже давно знищений. Наша знахідка наразі є єдиною достовірно підтвердженою на Криворіжжі (рис. 2). В 2007 р. ми виявили Marchantia polymorpha L. в acoціації з мохом Hygroamblystegium varium (Hedw.) Moenk. Вони зростають на другому горизонті лівого борту Карачунівського гранітного кар'єру, поруч з природним джерелом, яке витікає з тріщини в корінних породах. Географічні координати: широта $47^{0} 53^{\prime} 935^{\prime \prime}$, довгота $33^{0} 16^{\prime} 894^{\prime \prime}$, висота над рівнем моря $-8,6$ м.

Тут існує 2 локалітети, розташованих на відстані 12 м один від одного. Перший складається з 3 частин - велика ділянка суцільних таломів висотою 210 см і шириною 70 см на гранітній стінці, по якій постійно тече вода; одна маленька ділянка розмірами 60 х 40 см й друга маленька-розміром 50 х 30 см. Другий локалітет, розташований поруч із джерелом, має досить невеликі розміри - 30 х 40 см. Рослина зростає в достатньо стабільних умовах, повне знищення їй не загрожує.

\section{5. Нове місцезнаходження Galega officinalis L на Дніпропетровщині.}

Дуже цікавим у флористичному відношенні є майже не досліджений ботаніками район Кривого Рогу - Карачуни. Тут ми протягом 2004, 2007, 2008, 2009 і 2016 років знайшли значну кількість рідкісних созофітів.

Козлятник лікарський (Galega officinalis L.), занесений до Червоної книги Дніпропетровської області (2010) як зниклий вид. 28.06.2016 р. ми виявили популяцію козлятнику в заплаві правого берега р. Інгулець, в районі селища КДЗ. Пізніше, 06.07.16 р. ми провели додаткове обстеження і виявили ще 3 локаліте-

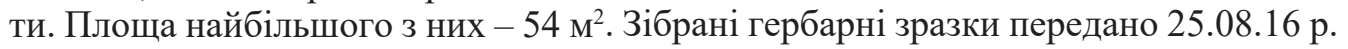
в гербарій $D S U$, а насіннєвий матеріал - у Науково-дослідний інститут біології ДНУ. В роботі Красової О. О. згадується знахідка Galega officinalis L. на півдні Криворіжжя в балці Зеленій, але докладного опису цієї ценопопуляції не подано [5]. В гербарії КБС $K R W$ * зборів козлятнику немає.

6. Нове на Дніпропетровщині і сдине на Криворіжжі місцезнаходження Sanguisorba officinalis L.

Поруч 3 козлятником лікарським нами було також виявлено 2 окремі локалітети родовика лікарського Sanguisorba officinalis L. В Червоній книзі Дніпропетровщини цей вид подано для Новомосковського, Павлоградського та Дніпропетровського районів. Для Криворіжжя зазначено лише одне місцезнаходження: ст. Довгинцеве, Котов! (1927), яке вже не існує. Ми знайшли родовик на правому і лівому березі р. Інгулець на Карачунах. Географічні координати: перша - широта $47^{0} 53^{\prime} 649^{\prime \prime}$, довгота $33^{\circ} 16^{\prime} 802^{\prime \prime}$, висота над рівнем моря 4,8 м; друга - широта $47^{0} 53^{\prime} 875^{\prime \prime}$, довгота $33^{0} 16^{\prime} 971^{\prime \prime}$, висота над рівнем моря 35,5 м. Гербарні зразки передано до гербарію ДНУ та Криворізького ботсаду, в якому є збори цього виду лише з басейну р. Базавлук, біля водоспаду, за межами Криворіжжя.

Разом 3 козлятником і родовиком були виявлені ценопопуляції інших созофітів - цибулі жовтіючої Allium flavescens Besser, цибулі подільської Allium podolicum (Asch, et Graebn.) Blocki ex Racib та дві великі популяції рястки Коха Ornithogalum kochii Parl. Перша - в районі кладовища с. КДЗ, на лівому схилі балки, площа близько 0,5 га. Друга - між старим гранітним кар'єром та залізничним мостом, площа 0,7 га. Тут на гранітних відслоненнях також зустрічаються поодинокі кущики кизильнику чорноплодого Cotoneaster melanocarpus Fisch. ex Blytt та дроку фарбувального Genista tinctoria L.

На західному схилі відвалу старого гранітного кар'єру, який розроблявся 31929 по 1946 роки, ми виявили і описали значний локалітет ефедри двоколосої Ephedra distachya L. Географічні координати: широта 49 53'922" довгота $33^{0} 17^{\prime} 011^{\prime \prime}$. Пагорб західної експозиції, висота 25 м, крутизна схилу $45^{\circ}$. Площа популяції - 18 х 14 м. Проективне покриття 80 \%, максимальна щільність популя-

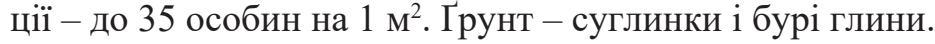




\section{7. Друга для Криворіжжя знахідка солодки голої Glycyrrhiza glabra L.}

У червні 2012 р. ми знайшли велику популяцію солодки голої Glycyrrhiza glabra L. біля оптового ринку в Дзержинському районі Кривого Рогу. Площа локалітету 405 м². Зібрані гербарні зразки передано в гербарій $D S U$. Цей вид занесений до Червоної книги України. Природоохоронний статус виду - неоцінений. Ареал виду в Україні - зрідка на півдні степової зони, переважно в прибережних р-нах Азовського та Чорного морів [19]. Для Дніпропетровщини [13] цей вид подається досить невизначено. Так, у «Бекетов, 1886; околиці м. Дніпропетровська, Тарасов, 1978, 2011, здичавіло!, Бурда! Цит. за Кучер., 2001. Категорія - 3 (рідкісний)». В «Конспекті флори...» В. В. Кучеревського (2004) дається просто посилання на В. В. Тарасова. В колекції природної флори КБС є 4 види солодки, в тому числі й Glycyrrhiza glabra L. В гербарії $K R W^{*}$ наявний зразок лише з 1 локалітету - із заплави р. Саксагань в районі с. Сергіївка, на північній околиці Кривого Рогу.

8. Новий і найбільший локалітет брандушки різнобарвної Bulbocodium versicolor (Ker Gawl.) Spreng на Дніпропетровщині.

У 2011 р. ми знайшли новий локалітет Bulbocodium versicolor (Ker Gawl.) Spreng за межами Кривого Рогу. Вид занесено до Червоної книги України та до Червоної книги Дніпропетровщини як вразливий $[15 ; 16]$. Раніше цей вид для Криворіжжя зазначався для с. Зелене, балка Зелена і балка Візирка, на півдні Криворіжжя [7]. Ми ж знайшли рослини на заході, в селі Кіровка Криворізького району і запропонували фахівцям Криворізького ботанічного саду здійснити експедицію для фіксації та опису цього локалітету. 01.04 .11 р. ми виїхали в с. Кіровку разом із співробітниками Саду - заступником директора з наукової роботи Кучеревським В. В. та інженером відділу природної флори Цуренковим А., де зробили опис найбільшої в Дніпропетровській області популяції брандушки. Загальна площа локалітету, на думку Кучеревського В. В., складає понад 1 га. На жаль, Кучеревський В. В. у своій наступній публікації не зазначив авторство Вікторії Тротнер у цій флористичній знахідці; також він вважає, що в цілому немає підстав для включення B. versicolor до категорії рідкісних чи зникаючих видів флори України [9].

Окремо зазначимо, що частина вивчених нами популяцій созофітів зазнає значного антропогенного навантаження, яке може призвести до їх повного знищення. Так, на Сланцевих скелях спостерігалися сліди викопування рослин голонасінника одеського, а місцезростання шипшини яблучної періодично випалюється. У зв'язку з цим лише термінові заходи з охорони цих локалітетів та раціональне і збалансоване природокористування у природних екосистемах можуть забезпечити довготривале існування популяцій цих рідкісних видів рослин.

Висновки. Таким чином, наведена нами інформація про знахідки рідкісних созофітів на Криворіжжі доповнює існуючі відомості про поширення цих видів на Дніпропетровщині. Разом з тим виявлені місцезнаходження Gymnospermium odessanum (DC.) Takht., Galega officinalis L. Rosa pomifera Herrm. та Glycyrrhiza glabra L. розширюють уявлення про ареал цих видів в Україні і дають можливість включити до нього південне Правобережне Степове Придніпров’я. Важливим є той факт, що у природній флорі України вперше зареєстровано ізольоване місцезнаходження Miscanthus sacchariflorus (Maxim.) Benth, який раніше відзначали тільки в умовах інтродукції. Крім того, наші дані підкреслюють созологічну цінність долини річки Інгулець у межах Карачунівських гранітних відслонень, оскільки знайдені нами види рослин занесено до Червоної книги Дніпропетровської області, а також виступають додатковим аргументом щодо необхідності створення на цій території ботанічних заказників місцевого значення.

\section{Бібліографічні посилання}

1. Гаевая Н. В. Мохообразные Днепропетровской области: дис. канд. биол. наук. Кривой Рог. 1971. 237 с. 
2. Дідух Я. П., Шеляг-Сосонко Ю. Р. Геоботанічне районування України та суміжних територій // Український ботанічний журнал. 2003. Т. 60. № 1. С. 6-17.

3. Каталог декоративних трав'янистих рослин ботанічних садів і дендропарків України: довідниковий посібник / за ред. С.П. Машковської. Київ. 2015. 282 с.

4. Красова О. О., Сметана О. М. Матеріали до оцінки перспективних степових компонентів екомережі Кривбасу («Балка Зелена») // Чорноморськ. бот. журн. 2012. Т. 8. № 4. C. 463-474.

5. Кучеревський В. В., Шоль Г. Л. Аналіз флори природно-заповідного фонду міста. Кривого Рогу // Фальцфейнівські читання. Херсон. Терра. 2001. С. 92-95.

6. Кучеревський В. В., Шоль $\boldsymbol{\Gamma}$. Н. Анотований список урбанофлори Кривого Рогу. Кривий Ріг. 2009. 71 с.

7. Кучеревський В. В. Атлас рідкісних і зникаючих рослин Дніпропетровщини. Київ. $2001.360 \mathrm{c}$.

8. Кучеревський В.В. Конспект флори Правобережного степового Придніпров'я. Дніпропетровськ. 2004. 292 с.

9. Bulbocodium versicolor (ker gawl.) Spreng. на Правобережному степовому Придніпров'ї (хорологія, біоморфологія, структура популяцій) / В. В. Кучеревський та ін. // Вісті Біосферного заповідника «Асканія-Нова». Т. 14. 2012. С. 456-464.

10. Определитель высших растений Украины / Д. Н. Доброчаева и др. Киев. 1987. 548 с.

11. Рахметов Д. Б., Щербакова T. О., Рахметов С. Д. Міскантус в Україні: інтродукція, біологія, біоенергетика. Київ. 2015. 158 с.

12. Сидоров B. M. Материалы для изучения Екатеринославской флоры // Ботанические записки, издаваемые при Ботаническом саде Императорского С.-Петербургского Университета проф. А. Бекетовым и проф. Хр. Гоби. Вып. XIV. С.-Петербург. 1897.

13. Тарасов В. В. Флора Дніпропетровської і Запорізькоі областей. Судинні рослини. Біолого-екологічна характеристика видів : монографія. Дніпропетровськ. 2005. 276 с.

14. Флора УССР. Київ. Т. I-XII. 1935-1965.

15. Червона книга Дніпропетровської області. Рослинний світ / автори-уклад. Б. О. Барановський, В. В. Тарасов; за ред. А. П. Травлєєва. Дніпропетровськ. 2010. 500 с.

16. Червона книга України. Рослинний світ / за ред. Я. П. Дідуха. Київ. 2009. 900 с.

17. Шоль Г. Н. Доповнення до флори міста Кривий Ріг // VI Ботанічні читання пам'яті Й. К. Пачоського: зб. тез доповідей Міжнародної наук. конф. (Херсон, 19.05.2014 22.05.2014). Херсон. 2014. С. 50-51.

18. Шоль Г. Флора Кривого Рогу: сучасний стан та созологічні аспекти // Вісник Львів. ун-ту. Серія біологічна. 2004. Вип. 36. С. 63-69.

19. Щербакова T. О. Інтродукція видів та сортів роду Miscanthus Anderss. в Національному ботанічному саду ім. М.М. Гришка НАН України // Вісті біосферного заповідника «Асканія-Нова»: науковий журнал. 2012. № 14. С. 309-313.

20. Mosyakin S. L., Fedoronchuk M. M. Vascular plants of Ukraine: a nomenclatural Checklist. Kiev. 1999. VVIV. 345 p.

Надійшла до редколегії 26.09.2016 p.

УДК 630.228 .7

В. А. Горейко

Днепропетровский нащиональный университет имени Олеся Гончара

\section{БИОЛОГИЧЕСКИЕ СПОСОБЫ ЗАЩИТЫ СТЕПНЫХ ЗЕМЕЛЬ ОТ ЭРОЗИОННЫХ ПРОЦЕССОВ}

Рассмотрены научные вопросы использования биологических способов защиты степных земель от эрозионных процессов и современного состояния лесных экосистем степи Украины. Разработаны основополагающие методы повышения продуктивности лесных экосистем с целью достижения высокого лесомелиоративного эффекта и

(C) В. А. Горейко, 2016 
защиты почв от эрозии. Исследования проведены в степном Верхнеднепровском регионе. Мелиоративная лесистость составляет 17,4 \%. Лесомелиоративный фон района состоит из овражно-балочных систем: Домотканской, Днепровской, Самотканьской и Омельчанской. Общая площадь составляет около 36 тыс. га. В этих условиях созданы лесные культурбиогеоценозы по типологии А. Л. Бельгарда. В настоящее время процесс оврагообразования завершен, эрозионные процессы прекращены.

Ключевые слова: лесная типология А. Л. Бельгарда, эталоны, водная эрозия, продуктивность.

\title{
В. О. Горейко \\ Дніпропетровський національний університет імені Олеся Гончара \\ БІОЛОГІЧНІ СПОСОБИ ЗАХИСТУ СТЕПОВОИХ ЗЕМЕЛЬ ВІД ЕРОЗІЙНИХ ПРОЦЕСІВ
}

Розглянуто наукові питання використання біологічних способів захисту степових земель від ерозійних процесів і сучасного стану різноманіття лісових екосистем степу України. Розроблено приорітетні методи підвищення продуктивності лісових екосистем з метою досягнення високого меліоративного ефекту та захисту грунтів від ерозії.

Ключові слова: лісова типологія О.Л. Бельгарда, еталони, водна ерозія, продуктивність.

\author{
V. A. Horeiko \\ Oles Honchar Dnipropetrovsk National University
}

\section{BIOLOGICAL APPROACHES TO STEPPE LANDS PROTECTION FROM EROSION}

The use of biological methods of steppe land protection from erosion and scientific issues of the current state of forest ecosystems in Ukrainian Steppe are under consideration. Basic methods of increasing forest productivity have been developed for effective forest reclamation and soil protection from erosion.

Our research has been conducted in the steppe area of Verkhniodniprovsk region. The area is covered by gullies and ravine systems: Domotkanska, Dniprovska, Samotkanska and Omelchanska. The total area is about $36,000 \mathrm{ha}$. In this area the artificial forest ecosystems have been created according to O.L. Belgard typology. Long-term research entailed in developed complex technology of eroded lands reclamation, which provides: 1) a long-standing organization of the territory (road network, water bodies, recreational and functional areas); 2) correction of the surface topography; 3) the use of intensive techniques of trees cultivation; 4) purposeful selection of trees and shrubs according to O.L. Belgard typology; 5) multifunctional use of agroforestry resources of the area.

During the period of 1960-1990 about 16,000 ha of protective forest plantations were created, 2,500 hectares of which are on the terraces. The reclaimed percentage of forest land cover is $17.4 \%$.

The approach to protect the soil from erosion is damming of surface runoff system of protective forest plantations in conjunction with waterside structures.

Currently, the ravines (about 500) formation is finished and erosion has been stopped at the area about 14,000 ha. Erosion control plantations, stepped terraces, impoundment and drainage banks reliably intercept melt and rain waters that drain from the fields, and protect agricultural land from erosion and runoff.

Keywords: Belgard forest typology, model, soil erosion by water, forest productivity.

Научные исследования биоразнообразия искусственных лесных культурбиогеоценозов позволяют выделить исторические эталоны степного лесоразведения, которые формировались с началом создания Велико-Анадольского лесничества 1843 года, и Старо-Бердянского лесничества - 1846 года. Затем последовало со- 